\title{
Pengaruh pemberian seng terhadap indeks fagositosis makrofag dan kadar nitric oxyde mencit balb/c yang terpapar lipopolisakarida e.coli
}

\author{
Nur Fardian', Andrew Johan², RA Kisdjamiatun RMD ${ }^{3}$
}

\begin{abstract}
Background : Immune system responses to LPS by activating macrophage and producing NO. Seng has play it's role as antioxidant and immunomodulator. The aim of this study is to prove the effect of zinc administration to macrophage phagocytosis index and NO level.

Method: The post test only controlled group design was conducted in 4 groups of Balb/C mice. Macrophage phagocytosis index and NO level was analyzed by one way anova, and proceeded with Bonferroni test.

Results : Means of macrophage phagocytosis index were 106,60( \pm 023.31$), 428.40( \pm 159.58)$, 285.70( \pm 90.45$)$ dan 208.07( \pm 43.85$)$ on control group, 30 ppm, 60 ppm and 120 ppm zinc administration group consecutively. There was a significant difference of macrophage phagocytosis index between control and intervention group $(p=0,000)$. Mean of NO level were $0,08( \pm 0,03), 0,12( \pm 0,06), 0,09( \pm 0,03)$ and 0,20 $\pm 0,08$ on control group, zinc dose group of $30 \mathrm{ppm}, 60 \mathrm{ppm}$ and $120 \mathrm{ppm}$ consecutively. There was significant difference on NO level between control and intervention group $(p=0,13)$.

Conclusion : Phagocytosis index of all intervention groups with zinc doses of $30 \mathrm{pp}$, 60 ppm and 120 ppm were significantly higher compare to control group. NO level in 120 ppm of zinc was significantly higher compare to control. Doses of 30 ppm had the highest phagocytosis index and doses of 120 ppm had the highest NO level.
\end{abstract}

Keywords : zinc, macrophage, NO, lipopolysaccharide

\begin{abstract}
ABSTRAK
Latar Belakang : Sistem imun tubuh merespons LPS dengan mengaktifkan makrofag dan memproduksi NO. Seng memiliki sifat sebagai antioksidan dan imunomodulator. Penelitian bertujuan untuk membuktikan pemberian seng berbagai dosis berpengaruh terhadap indeks fagositosis makrofag dan kadar NO.

Metode : The post test only controlled group design pada mencit Balb/C terbagi atas 4 kelompok. Perbedaan indeks fagositosis dan kadar NO dianalisis menggunakan uji one way ANOVA dan dilanjutkan dengan uji Bonferroni.

Hasil : Rerata indeks fagositosis makrofag adalah 106,60( $\pm 023,31), 428,40( \pm 159,58), 285,70( \pm 90,45)$ dan 208,07( $\pm 43,85)$ berturut turut untuk kelompok kontrol, perlakuan dosis 30 ppm, perlakuan dosis 60 ppm dan perlakuan dosis 120 ppm. Terdapat perbedaan bermakna atas indeks fagositosis makrofag antara kelompok kontrol dan perlakuan $(p=0,000)$. Rerata kadar NO

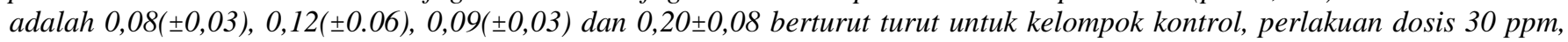
perlakuan dosis 60 ppm dan perlakuan dosis 120 ppm. Terdapat perbedaan bermakna atas kadar NO antara kelompok kontrol dan perlakuan $(p=0,013)$.

Kesimpulan : Indeks fagositosis makrofag seluruh kelompok perlakuan dengan dosis seng bertingkat 30 ppm, 60 ppm dan 120 ppm lebih tinggi secara bermakna dibanding kelompok kontrol. Kadar NO kelompok perlakuan dengan dosis seng 120 ppm lebih tinggi secara bermakna dibanding kelompok kontrol. Sedangkan dosis pemberian seng 30 ppm terbukti memiliki indeks fagositosis tertinggi dan dosis 120 ppm terbukti memiliki kadar NO tertinggi.
\end{abstract}

Kata kunci : seng, makrofag, NO, lipopolisakarida

\section{PENDAHULUAN}

Seng sebagai zat gizi mikro essensial bagi sistem imunitas khususnya pada proses inflamasi dan sepsis. Seng diperlukan dalam keadaan infeksi lokal atau sepsis guna merespon kerusakan agar dapat mengaktivasi fungsi respon sistem imun bawaan ${ }^{1}$, dan berperan dalam pembentukan NO oleh iNOS sebagai respons terhadap LPS pada mencit. LPS digunakan

\footnotetext{
I Bagian Ilmu Gizi Prodi Kedokteran Universitas Malikussaleh,

2 Bagian Biokimia Fakultas Kedokteran Universitas Diponegoro,

${ }^{3}$ Magister Ilmu Biomedik Universitas Diponegoro
}

dalam induksi endotoksemia eksperimental pada hewan coba. LPS merupakan aktivator bagi makrofag dan stimulan poten terhadap respons imun bawaan yang mampu membunuh bakteri, dan dapat menyebab kan perubahan patologis yang signifikan pada tubuh host. Molekul LPS dilepaskan dari permukaan bakteri dan selanjutnya menstismulasi makrofag dan sel endotel untuk memproduksi sitokin dan mediator inflamasi. Makrofag bersama neutrofil akan merubah molekul oksigen mejadi reactive oxygen intermediate (ROI). Aktivitas makrofag sebagai mekanisme pertahananan tubuh terhadap LPS dapat dinilai melalui kemampuan fagositosis (indeks fagositosis makrofag) dan kadar NO makrofag. 
Pengaruh seng sebagai zat gizi mikro penting dalam sistem imunitas khususnya pada proses inflamasi dan sepsis. Sejumlah penelitian telah membuktikan efek positif dari seng terhadap sistem imun termasuk dosis pemberiannya. Seng diperlukan dalam keadaan infeksi lokal atau sepsis guna merespon kerusakan agar dapat mengaktivasi fungsi respon sistem imun bawaan. Penelitian bertujuan untuk mengetahui pengaruh seng terhadap indeks fagositosis dan produksi NO pasca pemberian LPS sebagai induksi terjadinya endotoksemia.

\section{METODE}

Penelitian ini merupakan uji laboratoris dengan menggunakan mencit $\mathrm{Balb} / \mathrm{c}$ dan pendekatan the post test only controlled group design. Dua puluh empat ekor mencit yang dipaparkan lipopolisakarida E.coli i.p dibagi 4 kelompok : kelompok kontrol (K); kelompok perlakuan yang mendapat seng $30 \mathrm{ppm} / \mathrm{hari}(\mathrm{P} 2)$; seng $60 \mathrm{ppm} / \mathrm{hari}(\mathrm{P} 2)$; seng $120 \mathrm{ppm} / \mathrm{hari}$ (P3) selama 11 hari. Pemberian LPS dilakukan pada hari ke 12, dan seng dilanjutkan hingga hari ke 14. Kemudian dilakukan pemeriksaan indeks fagositosis dan kadar NO. Indeks fagositosis berdasarkan persentase sel yang memfagosit partikel latex yang dihitung pada 120 sel dikali rerata jumlah partikel yang difagosit pada sel yang positif, sedangkan kadar NO diukur dari konsentrasi NO yang terdapat dalam supernatan kultur makrofag, diukur dengan metode Griess.

Analisis statistik indeks fagositosis dan kadar NO menggunakan ANOVA dilanjutkan dengan uji Bonferroni.

\section{HASIL}

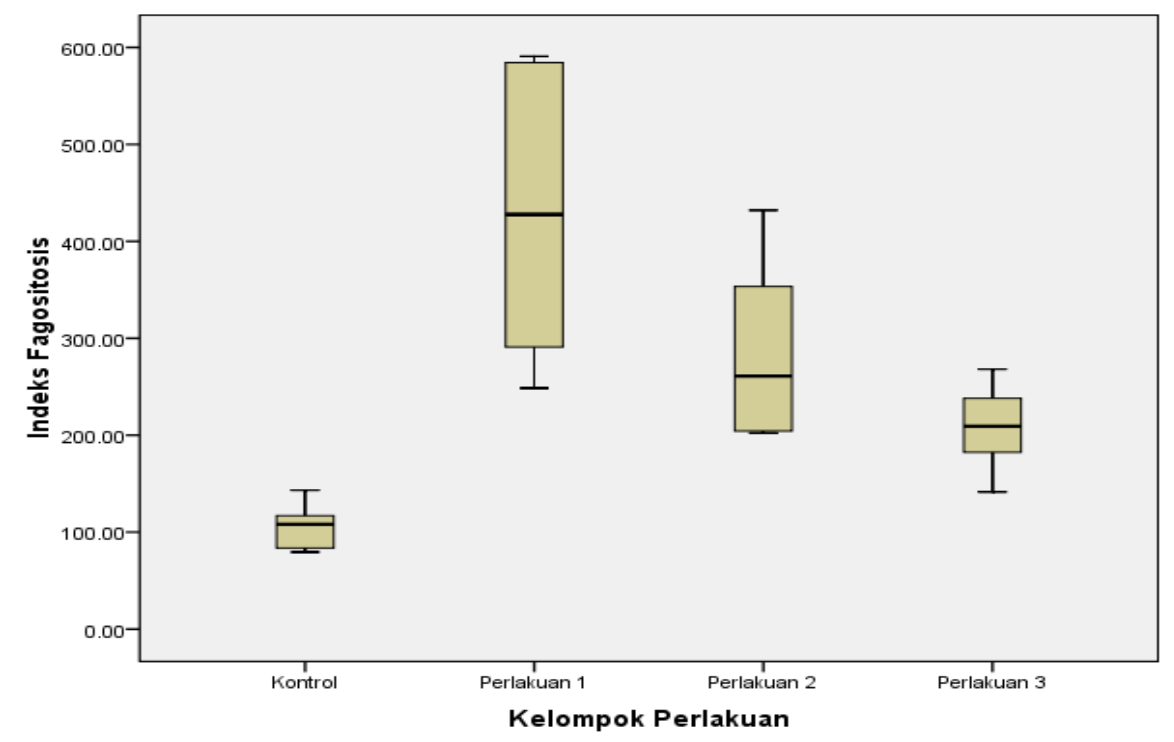

Gambar 1. Box plot indeks fagositosis makrofag

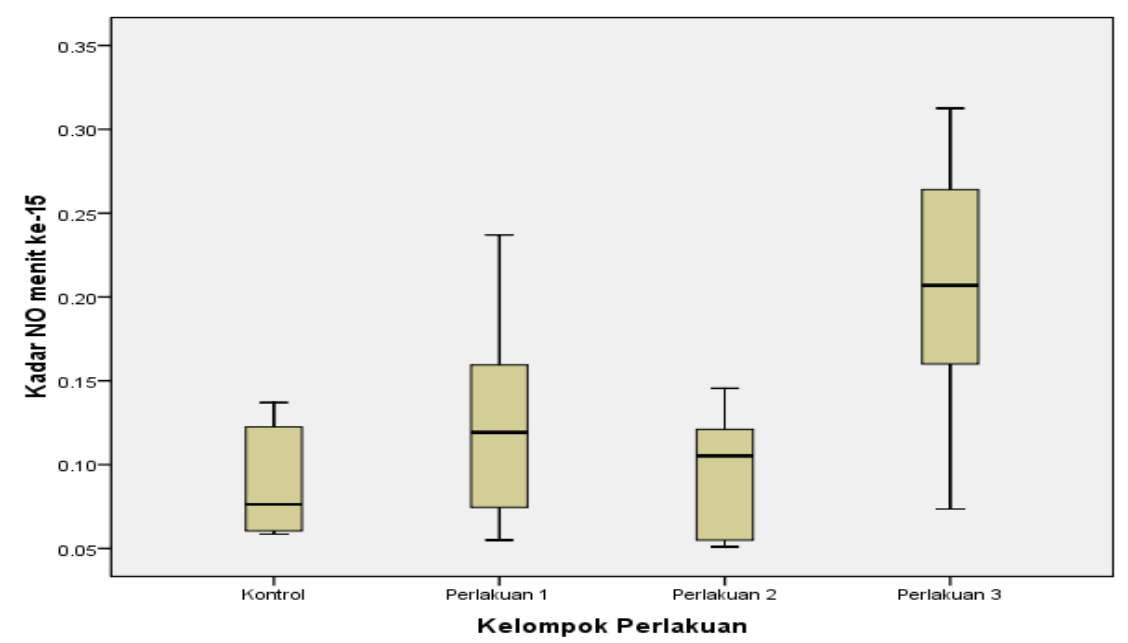

Gambar 2. Box plot kadar NO 
Penelitian ini meggunakan 24 ekor mencit betina Balb/C berumur 8-10 minggu dan berat badan 20-30 gram yang telah diadaptasi selama 7 hari, kemudian diberikan seng sesuai dosis masing-masing kelompok selama 11 hari dan hari ke 12 diberikan LPS E.coli sebanyak LPS $0,1 \mathrm{mg} / \mathrm{mencit}$ dalam volume 250 $\mu \mathrm{L}$ larutan salin steril. Pemberian seng dilanjutkan hingga hari ke-14. Tidak ada tikus yang mati selama penelitian. Setelah itu mencit diterminasi dan diambil cairan peritonealnya lalu dihitung indeks fagositosis dan kadar NO pada tiap kelompok. Alur penelitian dan hasil tercantum pada gambar 3 .

Terdapat perbedaan bermakna antara indeks fagositosis makrofag kelompok K $(106,60 \pm 23,30)$ dibandingkan dengan masing masing kelompok perlakuan P1 $(428,40 \pm 159,58)$, P2 $(285,70 \pm$ 90,45) dan P3 $(208,07 \pm 43,85)$ dengan nilai $p<0,05$. Uji post host antar kelompok menunjukkan : K-P1 $(0,000)$, KP2 (0,000), K-P3 (0,005), P1-P3 (0,004), tetapi tidak didapatkan perbedaan yang bermakna antara P1-P2 $(0,210)$ dan P2-P3 $(0,561)$. Oleh karena itu dapat diartikan bahwa dibandingkan kelompok kontrol, indeks fagositosis seluruh kelompok perlakuan lebih tinggi. Rerata indeks fagositosis paling tinggi terdapat pada kelompok P1 senilai $428,40(\Delta=321,8)$, diikuti kelompok P2 dengan nilai 285,70 $(\Delta=179,1)$, dan kelompok P3 dengan nilai 208,07 $(\Delta=101,47)$ serta paling rendah pada kelompok kontrol dengan nilai 106,60. Rerata indeks fagositosis makrofag mengalami kecenderungan penurunan seiring dengan peningkatan dosis seng. Pemberian seng menunjukkan pengaruh terhadap indeks fagositosis.

Terdapat perbedaan bermakna antara indeks fagositosis makrofag kelompok $\mathrm{K} \quad(0,08 \pm 0,03)$ dibandingkan dengan kelompok perlakuan P3 $(0,20 \pm 0,08)$ dan $\mathrm{P} 2(0,09 \pm 0,03)$ dengan kelompok perlakuan P3 dengan nilai $\mathrm{p}<0,05$. Uji post host antar kelompok menunjukkan : K-P3 $(0,010)$, dan P2-P3 $(0,034)$, tetapi tidak didapatkan perbedaan yang bermakna antara K-P1(1,000), K-P2 (1,000), P1-P2 $(1,000)$ dan P1-P3 $(0,228)$. Rerata kadar NO kelompok perlakuan lebih tinggi dibanding kelompok kontrol. Rerata kadar NO paling tinggi terdapat pada kelompok P3 senilai $0,20(\Delta=0,12)$, kelompok P1 $0,12(\Delta=0,04)$, dan kelompok P2 $0,09(\Delta=0,01)$ serta paling rendah pada kelompok kontrol. Peningkatan kadar NO terjadi sesuai dengan peningkatan dosis seng. Pemberian seng berpengaruh terhadap kadar NO mencit Balb/C yang terpapar LPS.

\section{DISKUSI}

Sitokin proinflamasi berpengaruh langsung terhadap homeostasis seng. Seng merupakan komponen penting bagi thymulin, hormon yang berperan dalam maturasi dan differensiasi sel T. Seng berperan menginduksi aktivasi sel $\mathrm{T}$ atau alterasi produksi limfokin, dan mengaktifkan makrofag guna melakukan bacterial clearance. Ekspresi gen IL-2 dan IFN- $\gamma$ (sitokin Th1) bergantung pada seng, di mana defisiensi seng menurunkan sitokin sel Th1 IFN- $\gamma$ dan IL-12 $2^{2}$. IL-12 di produksi oleh makrofag-monosit yang mengalami stimulasi dan bergantung pada seng. IFN- $\gamma$ dan IL-12 bersama bersama berperan dalam membunuh parasit, bakteri dan virus oleh makrofag. Aktvitas sitotoksik sel NK juga menurun pada keadaan defisiensi seng ${ }^{3,4}$. Makrofag yang teraktivasi mengalami peningkatan kemampuan fagositosis dan produksi ROI sehingga kuman dapat lebih banyak dieliminasi. konsentrasi seng yang tinggi justru bersifat menginhibisi dan berefek negatif bagi sistem imun dan perubahannya mirip dengan keadaan defisiensi seng. Konsentrasi seng sebanyak 7-8 kali lipat menghentikan produksi IFN- $\gamma^{5}$. Penurunan indeks fagositosis pada penelitian ini dapat terjadi karena pengaruh pertama : adanya penurunan enzim ATP-ase pada membran sel makrofag. Konsentrasi seng yang tinggi dapat mengaktivasi makrofag dengan menghambat membran ATP-ase. Enzim ATP-ase diperlukan oleh makrofag untuk menghidrolisis ATP dalam proses polimerisasi aktin sehingga fagositosis dapat terjadi. Fagositosis akan menurun sebagai akibat sedikitnya molekul Gaktin yang terpolimerisasi saat lateks berikatan dengan reseptor makrofag. Hal ini terjadi karena pemberian diet tinggi seng dapat menurunkan enzim tersebut ${ }^{6}$. Kedua : pemberian seng dalam dosis tinggi berefek negatif dan perubahannya mirip dengan keadaan defisiensi seng. Fungsi sel T dihambat pasca pemberian seng dosis tinggi, sehingga menyebabkan penurunan produksi IFN- $\gamma$ yang tidak cukup banyak untuk mengaktivasi makrofag, sehingga kemampuan fagositosis dan killing makrofag menurun ${ }^{7}$.

LPS sering digunakan dalam induksi endotoksemia eksperimental pada hewan coba di laboratorium. LPS yang terikat dengan reseptor LPS di membran sel akan mengaktivasi monosit, makrofag, neurofil dan sel endotel di paru yang selanjutnya akan menghasilkan NO dalam jumlah besar melalui iNOS. Peningkatan produksi NO melalui iNOS berkontribusi terhadap respons imun pada endotoksemia. Makrofag yang teraktivasi LPS merupakan sumber iNOS yang menghasilkan NO. NO bereaksi dengan anion superoksida untuk menghasilkan oksidan poten peroksinitrit. Peroksinitrit terlibat dalam pembentukan hidroksiradikal yang mengakibatkan induksi stres nitrosative, antara lain destruksi protein dan enzim pada membran sel pada defisisensi seng. Produksi NO dan IL-1 $\beta$ yang berlebihan akan mengakibatkan efek reactive oxygen species $(\mathrm{ROS})^{8}$. Fagositosis oleh makrofag dipengaruhi oleh interferon- $\gamma$ (IFN- $\gamma$ ) dan dalam proses tersebut makrofag akan mengeluarkan reactive oxygen intermediate (ROI) dan nitric oxide 
(NO) untuk proses destruksi intraselular. Ikatan LPS pada CD14 memicu aktivasi TLR4 dan meneruskan sinyal bagi molekul lain. Sinyal TLR4 mengaktifkan faktor transkripsi seperti nuclear factor-kappa B (NF$\kappa \mathrm{B}$ ), yang merupakan suatu protein faktor transkripsi terdapat pada makrofag, akan teraktivasi akibat toksin dari bakteri seperti LPS. Proses ini akan menyebabkan peningkatan mediator proinflamasi seperti IL-8, TNF$\alpha$, intercellular adhesion molecule, serta cyclooxygenase-2. Antioksidan seperti seng dapat melemahkan efek paparan dari lipopolisakarida dan memblok produksi NF-кB ${ }^{9}$. Defisiensi seng merupakan pemicu positif bagi terjadinya translokasi NF-кB yang menyebabkan terjadinya efek proinflamasi. Walaupun seng berefek anti inflamasi, namun sejumlah aksi dapat bersifat proinflamasi.

\section{SIMPULAN}

Indeks fagositosis makrofag seluruh kelompok perlakuan dengan dosis seng bertingkat $30 \mathrm{ppm}, 60$ ppm dan 120 ppm lebih tinggi secara bermakna dibanding kelompok kontrol. Kadar NO kelompok perlakuan dengan dosis seng $120 \mathrm{ppm}$ lebih tinggi secara bermakna dibanding kelompok kontrol. Sedangkan dosis pemberian seng $30 \mathrm{ppm}$ terbukti memiliki indeks fagositosis tertinggi dan dosis 120 ppm terbukti memiliki kadar NO tertinggi.

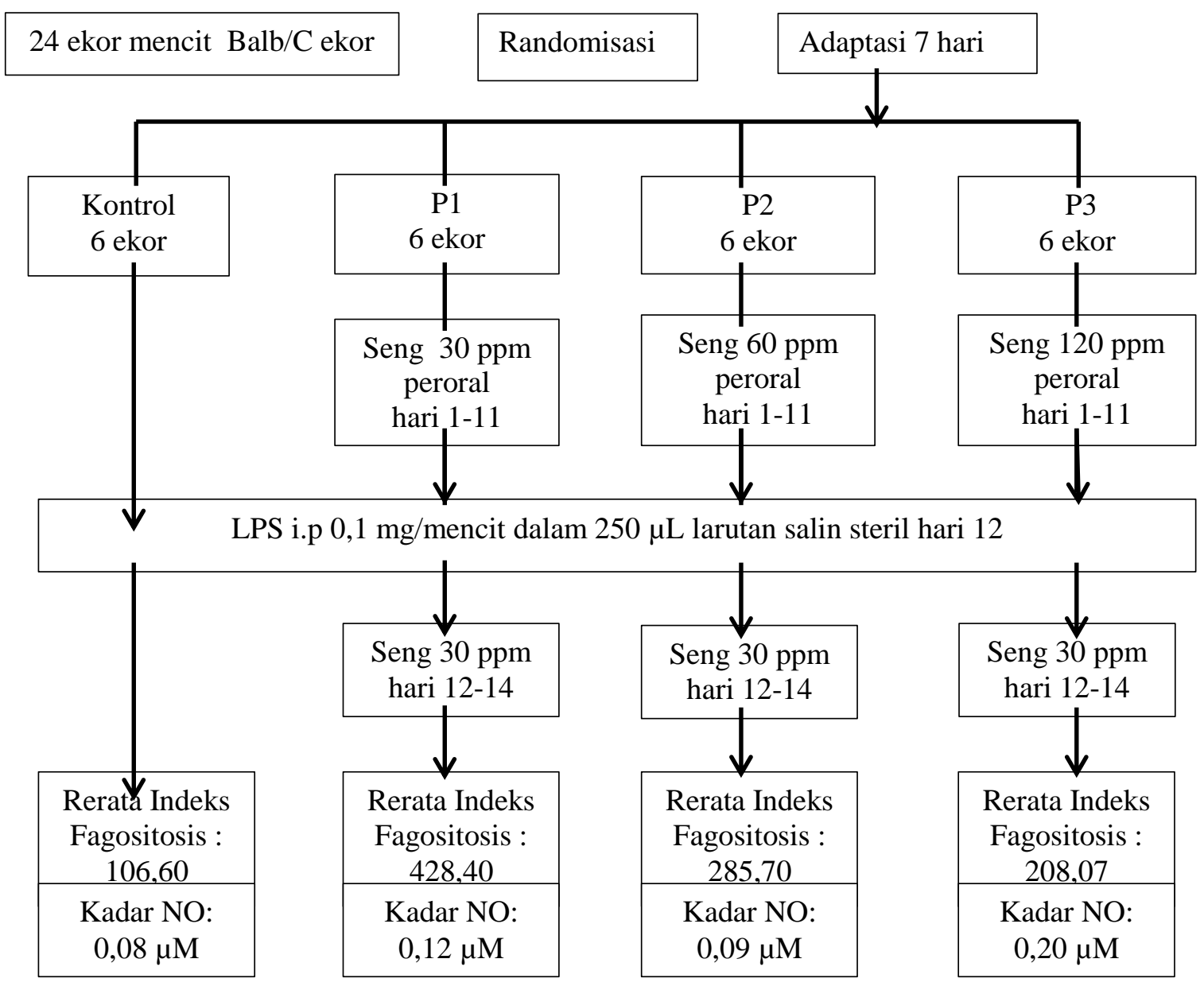

Gambar 3. Alur dan ringkasan penelitian

\section{DAFTAR PUSTAKA}

1. Kohler J, Blass A, Williams M, Faldetta K, Kelly E, editors. LPS upregulates cellular demand for $\mathrm{Zn2+}$ in murine macrophages. 5th annual academic surgical congress association for academic surgery and society of university surgeons 2010; Boston, MA.

2. Metz CH, Schroder AK, Overbeck S, Kahmann L, Plumakers B, Rink L. T-helper type 1 cytokine release is enhanced by in vitro zinc supplementation due to increased NK cell. Nutr. 2007;23:157-63.

3. Prasad AS. Zinc: role in immunity, oxidative stress and chronic inflammation. Curr Op Clin Nutr Metab Care 2009;12:646-52.

4. Prasad AS. Zinc: Mechanisms of Host Defense Experimental Biology meeting: Micronutrient Regulation of Host-Pathogen Interactions; San Francisco, CA, 2006. 
5. Rink L, Kirchner H. Zinc altered immune function and cytokine production. In: Hambidge M, Cousin R, Costello R, editors. Zinc and health : current status and future directions; November 4-5, 1998; Maryland, USA: J Nutr; 1998. p. 1407S-11S.

6. Yuniastuti A, Nugrahaningsih W, Zunikhah Z. Efektivitas seng (Zn) sebagai imunostimulan dalam produksi reactive oxygen intermediate pada mencit Balb/C yang diinfeksi Salmonella typhimurium. Biosaintifika. 2010;2(1):53-60.

7. Ibs K-H, Rink L. Zinc-Altered Immune Function. J Nutr. 2003;133:1452S-5S.
8. Miyazaki T, Takenaka $\mathrm{T}$, Inoue $\mathrm{T}$, Sato $\mathrm{M}$, Miyajima Y, Nodera $\mathrm{M}$, et al. Lipopolysaccharide-induced Overproduction of Nitric Oxide and Overexpression of iNOS and Interleukin-1 $\beta$ Proteins in Zinc-deficient Rats. Biol Trace Elem Res. 2012;145:375-81.

9. Overbeck S, Rink L, Haase H. Modulating the immune response by oral zinc supplementation : a single approach for multiple diseases Arch Immunol Ther Exp. 2008;56:15-30. 